\title{
Effects of winter recreation on northern ungulates with focus on moose (Alces alces) and snowmobiles
}

\author{
Grant Harris • Ryan M. Nielson • Todd Rinaldi • \\ Thomas Lohuis
}

Received: 9 October 2012 / Revised: 27 February 2013 / Accepted: 25 June 2013 / Published online: 28 July 2013

(C) The Author(s) 2013. This article is published with open access at Springerlink.com

\begin{abstract}
Winter recreation can displace ungulates to poor habitats, which may raise their energy expenditure and lower individual survivorship, causing population declines. Winter recreation could be benign, however, if animals habituate. Moreover, recreation creates trails. Traveling on them could reduce energy expenditure, thereby increasing ungulate survivorship and generating population benefits. Balancing recreation use with wildlife stewardship requires identifying when these effects occur. This task would be simpler if guidelines existed to inform assessments. We developed and tested such guidelines using two approaches. First, we synthesized literature describing the effects of winter recreation - motorized and nonmotorized - on northern ungulates. This synthesis enabled formulating six guidelines, while exposing two requiring further attention (ungulate habituation and displacement). Second, we tested these two guidelines and evaluated the others by quantifying the
\end{abstract}

Communicated by C. Gortázar

G. Harris

USDA Forest Service, 3301 C Street, Anchorage, AK 99503, USA

R. M. Nielson

WEST, Inc., 200 South Second St., Suite B,

Laramie, WY 82070, USA

T. Rinaldi

Alaska Department of Fish \& Game, 1800 Glenn Highway, Suite 2,

Palmer, AK 99645, USA

T. Lohuis

Alaska Department of Fish and Game, 333 Raspberry Road,

Anchorage, AK 99518-1599, USA

Present Address:

G. Harris $(\bowtie)$

United States Fish and Wildlife Service, P.O. Box 1306,

Albuquerque, NM 87103, USA

e-mail: grant_harris@fws.gov behavioral responses of moose to snowmobiles, in two areas of south-central Alaska, differing by snowmobile predictability. For each location, we modeled moose preferences during the snowmobile period using different combinations of eight variables - static (elevation and slope), biotic (habitat and cover), and anthropogenic (distance to roads, railroads, snowmobile trails, and trail density). We identified the model with the most support and used it to estimate parameter coefficients for pre- and post-recreation periods. Changes in coefficients between periods indicated snowmobile effects on moose. Overall, we produced and evaluated six guidelines describing when winter recreation is potentially detrimental to ungulates as follows: (1) when unpredictable, (2) spanning large areas, (3) long in duration, (4) large spatial footprint, (5) nonmotorized, and (6) when animals are displaced to poor quality habitats.

Keywords Alces alces $\cdot$ Moose $\cdot$ Recreation $\cdot$ Resource selection function $\cdot$ Snowmobiles $\cdot$ Ungulate

\section{Introduction}

In northern ecosystems, snowmobiling and other forms of winter recreation can displace ungulates into habitats of poor quality, which decreases the animals' nutrient intake and increases their physiological stress and energy expenditure (White 1983; Colescott and Gillingham 1998; Tyler 1991; Seip et al. 2007; Creel et al. 2002). These outcomes reduce fitness of ungulates, whereby disease, predators, and starvation further lower individuals' survival and reproduction, thereby contributing toward population decreases (Gasaway and Coady 1974; Hobbs 1989; Van Ballenberghe and Ballard 1994).

Alternatively, winter recreation could provide benefits, like compacted trails. It is easier for animals to traverse these trails relative to deep snow (James and Stuart-Smith 2000; 
Bunnell et al. 2006; Rinaldi 2010). Ungulates may also use the packed trails to range more widely, thereby obtaining safety, thermal cover, or better forage, which reduces density-related constraints on resource use (Dorrance et al. 1975; Richens and Lavigne 1978; James and Stuart-Smith 2000). These effects may increase ungulate survival and reproduction, increasing population sizes.

Since ungulate responses to recreation can result in this variety of physiological, behavioral, and population outcomes, an understanding of which consequence ensues in a particular setting provides the foundation for science-based management. Currently, despite many studies examining recreation effects on ungulates, the conclusions are unorganized and can appear contrasting. This limits the use of scientific information to identify the effects of recreation on ungulates or understand the circumstances describing when negative effects are likely to occur, thereby impeding appropriate management responses. Hence, a synthesis of scientific results formulated into a set of criteria, or guidelines, which describe when winter recreation is most likely to negatively impact ungulates, is necessary. Such guidelines would be useful for evaluating, and therefore better managing, situations where winter recreation and ungulates occur. The guidelines would also reduce needs for embarking on potentially lengthy and expensive investigations to examine recreation's effects on ungulates for every specific site or situation.

We developed and evaluated these guidelines by combining two approaches. First, we reviewed literature describing the effects of winter recreation - motorized and nonmotorized - on northern ungulates [elk (Cervus canadensis), caribou (Rangifer tarandus), muskoxen (Ovibos moschatus), white-tailed deer (Odocoileus virginianus), mule deer (Odocoileus hemionus), and moose (Alces alces)]. We synthesized data describing ungulate responses to these different disturbances, such as distances moved, disturbance duration, and the distances between the recreation and the animal at the time of first disturbance. We sought commonalities in ungulate responses to winter recreation across geographical locations, circumstances, and species.

This synthesis enabled formulating the guidelines and highlighted two guidelines requiring more attention. One topic was determining if recreation activity, when predictable in location and time, would have less effect than unpredictable recreation. Animals could habituate with predictable recreation, thereby minimizing the potential effects. The second issue was the displacement of ungulates to poor quality habitats for extended periods. Such displacement could negatively affect ungulates more than direct human provocation (Nellemann et al. 2000). Both guidelines were described regarding motorized and nonmotorized recreation, with many authors discussing the possibilities (e.g., Eckstein et al. 1979; Tyler 1991;
Nellemann et al. 2000), but few quantifying them (e.g., Colescott and Gillingham 1998; Seip et al. 2007).

The second approach tested these two guidelines, by using field studies to examine the relationships between the predictability of recreation and ungulate displacement (geographic and temporal). We focused on moose inhabiting two sites with snowmobile recreation, on the Kenai Peninsula of southcentral Alaska. One location, Juneau Creek, had snowmobile recreation predictable in location and time, whereas the second area, Placer Valley, had unpredictable snowmobiling. We compared moose responses across these sites based on global positioning system (GPS) location data and resource selection functions (RSF) (Sawyer et al. 2006, 2007, 2009). Our goal was to synthesize information from both steps, to build and evaluate criteria describing when the effects of winter recreation may be detrimental to ungulates. Such criteria would serve as a guide for managers to predict the responses of northern ungulates to recreation in any given area.

\section{Materials and methods}

\section{Literature review}

We reviewed published studies to evaluate the potential for snowmobile activity and other forms of winter recreation to affect ungulates (positive or negative). We searched for publications published before September 2012 with the Web of Science, Wildlife \& Ecology Studies Worldwide, and Google Scholar search engines.

\section{Study location}

To compliment this synthesis, we examined moose habitat use in response to winter recreation for moose inhabiting the Kenai Peninsula in south-central Alaska, USA $(23,310 \mathrm{~km} 2)$. The western third of the Peninsula consists of lowland plains and lakes (sea level). Glaciated mountains and ice fields dominate the remainder, with peaks reaching approximately $2,000 \mathrm{~m}$. Analyses occurred in two separate areas, which differed by the spatial extent and predictability of snowmobile use (Fig. 1). Placer Valley (northeast peninsula; $244 \mathrm{~km} 2$ ) has unpredictable snowmobile use throughout the entire valley (no designated trails), and recreationists can travel extensively throughout the valley. Snowmobile activity within Juneau Creek (central peninsula; $443 \mathrm{~km} 2$ ) is predictable, as the majority of use is confined to one trail (Resurrection Trail; USDA FS, unpublished).

\section{Moose captures}

In the months of March and November of 2006 and 2007, employees from the Alaska Department of Fish and Game 


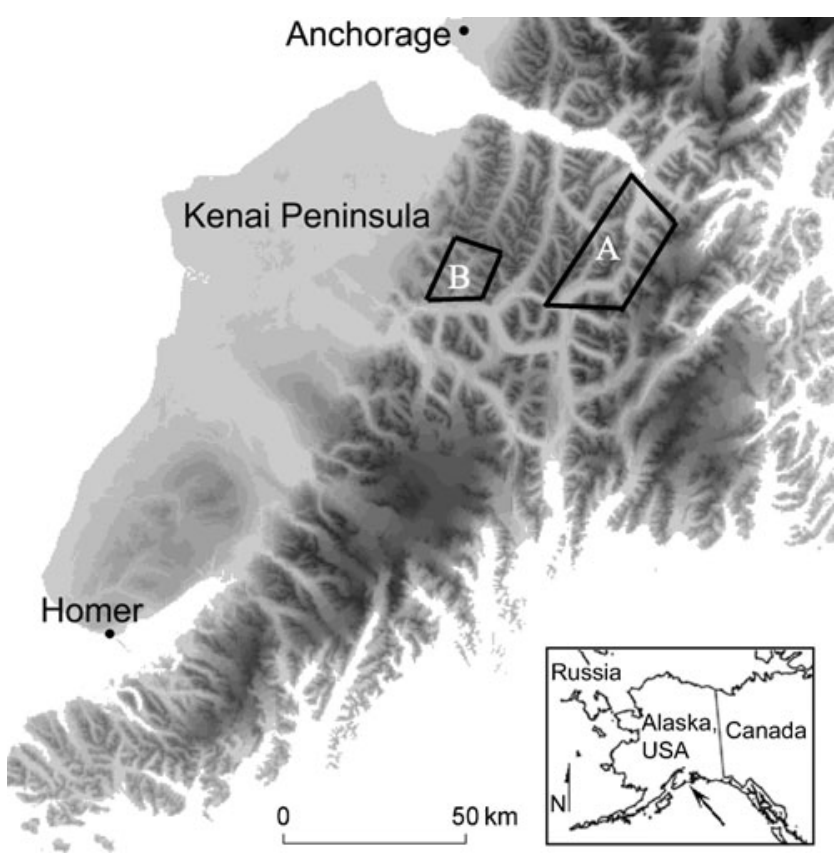

Fig. 1 This study evaluated moose behavioral responses to snowmobile recreation on the Kenai Peninsula of south-central Alaska. Placer Valley (polygon with white $A$ ) had snowmobile recreation unpredictable in location and time. Juneau Creek (polygon with white $B$ ) had predictable snowmobile recreation. Gray shading indicates elevation, ranging from sea level (white) to high altitudes (black)

captured and fit female moose (cows) on the Kenai Peninsula with GPS-enabled radio collars. Moose were darted via helicopter or from the ground and immobilized with a combination of carfentanil citrate and xylazine hydrochloride (ZooPharm, Fort Collins, CO, USA). Adult cows received collars because they are the most abundant sex and age class of moose and therefore those most likely encountered by recreationists. Moreover, cows are typically pregnant during winter and their nutritional condition affects calf recruitment the following year (Thorne et al. 1976). All field and capture methods were approved by the Alaska Department of Fish and Game, Animal Care and Use Committee, Assurance No. 06-03.

In Placer Valley, we began the study with four moose wearing Tellus collars (Followit AB, Lindesberg, Sweden) and seven moose wearing Lotek GPS collars (Lotek Wireless, Inc. New Market, ON, USA; Table 1). Between winters, some moose left the valley, and other GPS collars either failed or consumed all power. Therefore, during the winter of 20072008, we received data from two moose in this area.

At Juneau Creek, the study began by fitting eight moose with collars manufactured by Telonics Inc. (Telonics, Mesa, AZ, USA), three moose with ATS GPS collars (Advanced Telemetry Solutions, Inc., Isanti, MN, USA) and two moose with Televilt collars (Table 1). A second capture fixed 11 Telonics collars on moose before the winter of 2007-2008.

In both locations, fix intervals varied among GPS collars. This occurred to either extend battery life or to provide fine- scale movements of moose for a separate study (Table 1). All GPS collars had an average fix success $>97 \%$ during the study period.

Mapping snowmobile trails

We photographed snowmobile trails at Placer Valley and Juneau Creek during the winter of 2006-2007 (March 25, 2007). We conducted aerial photography in March since the bulk of snowmobile activity occurs in late winter, and light conditions minimized shadows in the photographs (USDA FS, unpublished). We used a 206 aircraft flying at $1,000 \mathrm{~m}$, with a Nikon D2X digital camera (focal length of $28 \mathrm{~mm}$ ). For Placer Valley, individual photos were stitched into mosaics using Autopano software (Kolor Inc., Challes-les-Eaux, France). Some photos were stitched by hand due to lack of overlap. The stitched scenes were georeferenced to digital orthophoto quadrangles (DOQs) (1996-2000) using ERDAS ERMapper software (Intergraph ERDAS, Norcross, GA, USA). All snowmobile trails were digitized from the georeferenced photos, using ArcMap 9.3 (ESRI, Redlands, CA, USA). We quantified snowmobile trail location and density based on the digitized layer. Because the majority of snowmobile activity in Juneau Creek occurred along the Resurrection Trail (USDA FS, unpublished), the geographical location for Resurrection Trail was used as a surrogate for the location of snowmobile trails in Juneau Creek.

\section{Snow depth}

For Placer Valley, the Placer Railroad Station cataloged snow depth (http://www.akrr.com/wthr/). For Juneau Creek, we relied on data gained by the closet SNOTEL site, located at Summit Creek (http://www.wcc.nrcs.usda.gov/snotel/Alaska/ alaska.html). At each location, we quantified the mean depth of snow, or snow accumulation, for each period of analysis (pre-, during, and post-recreation activity). Including snow depth enabled us to account for its effects on moose behavior, thereby improving our interpretation of moose reactions to snowmobile recreation.

\section{Periods of snowmobile use}

Data collection in Placer Valley covered two winters, each with three periods. These periods were defined by snow depth and the presence or absence of snowmobile activity. Preseason in the first winter, before snowmobile activity commenced, occurred from December 1, 2006 through January 3, 2007. There was a low snow period (mean $7.4 \mathrm{~cm}$; CV 72.7) from December 1, 2006 to December 19, 2006 and a high snow period (mean $98.0 \mathrm{~cm}$; CV 12.5) 
Table 1 Attributes describing the sampling used to evaluate behavioral responses of moose to varying spatial extent and predictability of snowmobile recreation at two study sites located on the Kenai Peninsula of south-central Alaska

\begin{tabular}{|c|c|c|c|c|c|c|c|c|}
\hline Study site & Period & Dates & GPS collar type & Number & $\begin{array}{l}N \\
\text { total }\end{array}$ & $\begin{array}{l}\text { GPS fix } \\
\text { interval }\end{array}$ & $\begin{array}{l}\text { Mean \# locations/ } \\
\text { moose }\end{array}$ & $\mathrm{SE}$ \\
\hline \multirow[t]{6}{*}{ Placer } & Preseason (LS) & $\begin{array}{l}\text { December 1, 2006-December } \\
\quad 19,2006\end{array}$ & Lotek/Televilt & $7 / 4$ & 11 & $4 \mathrm{~h} / 15 \mathrm{~min}$ & 670.7 & 236.0 \\
\hline & Preseason (HS) & $\begin{array}{l}\text { December 20, 2006-January } \\
\quad 3,2007\end{array}$ & Lotek/Televilt & $7 / 4$ & 11 & $4 \mathrm{~h} / 15 \mathrm{~min}$ & 464.3 & 158.9 \\
\hline & During season & $\begin{array}{l}\text { January 4, 2007-March } \\
\quad 31,2007\end{array}$ & Lotek/Televilt & $7 / 3$ & 10 & $1 \mathrm{~h} / 15 \mathrm{~min}$ & $2,778.5$ & 868.4 \\
\hline & Preseason & $\begin{array}{l}\text { December 1, 2007-January } \\
\quad 3,2008\end{array}$ & Lotek & 2 & 2 & $4 \mathrm{~h}$ & 207.5 & 20.5 \\
\hline & During season & $\begin{array}{l}\text { January 4, 2008-March } \\
\quad 6,2008\end{array}$ & Lotek & 2 & 2 & $1 \mathrm{~h}$ & 930.0 & 579.0 \\
\hline & Postseason & $\begin{array}{l}\text { March 7, 2008-March } \\
\quad 31,2008\end{array}$ & Lotek & 1 & 1 & $1 \mathrm{~h}$ & 597.0 & - \\
\hline \multirow[t]{3}{*}{ Juneau } & During season & $\begin{array}{l}\text { December 14, 2006-February } \\
\quad 15,2007\end{array}$ & Telonics/ATS/Televilt & $8 / 3 / 2$ & 13 & $2 \mathrm{~h} / 1 \mathrm{~h} / 15 \mathrm{~min}$ & $1,603.7$ & 476.1 \\
\hline & Postseason & $\begin{array}{l}\text { February 16, 2007-March } \\
\quad 31,2007\end{array}$ & Telonics/ATS/Televilt & $8 / 3 / 2$ & 13 & $2 \mathrm{~h} / 1 \mathrm{~h} / 15 \mathrm{~min}$ & $1,140.2$ & 351.3 \\
\hline & Entire winter & $\begin{array}{l}\text { December 1, 2007-March } \\
\quad 31,2008\end{array}$ & Telonics & 11 & 11 & $1 \mathrm{~h}$ & $2,105.9$ & 171.2 \\
\hline
\end{tabular}

Preseason indicates the period before snowmobile recreation, during season represents the period when snowmobile recreation occurred, while postseason categorizes the period after snowmobile recreation happened

$L S$ low depth of snow, $H S$ high depth of snow

from December 20, 2006 to January 3, 2007 (Table 1). Since snow depth tends to increase over the winter, dividing this preseason enabled us to evaluate if deep snow altered moose behaviors in the absence of snowmobile activity. This information helped identify the effects of snowmobile activity on moose habitat choices, beyond those influenced by snow depth. The third period described when snowmobile recreation occurred (January 4, 2007-March 31, 2007; mean snow depth $74.7 \mathrm{~cm}$; CV 24.9). This winter lacked a postseason (Table 1).

The second winter had one preseason from December 1, 2007 to January 3, 2008 (mean snow depth $16.5 \mathrm{~cm}$; CV 95.2). Since snow depth was relatively low throughout this period, we did not divide it. Snowmobiles occurred from January 4, 2008 to March 6, 2008 (mean snow depth $50.2 \mathrm{~cm}$; CV 26.2). The third period for this winter was a postseason from March 7, 2008 to March 31, 2008 (mean snow depth $42.8 \mathrm{~cm}$; CV 54.5). Then, snowmobile recreation did not occur, although snow cover and trails could persist (Table 1).

In Juneau Creek, snowmobile recreation occurred from December 14, 2006 to February 15, 2007 (mean snow accumulation $=37.1 \mathrm{~cm} ; \mathrm{CV} 17.2$ ). Postseason was February 16, 2007-March 31, 2007 (mean snow accumulation $=44.8 \mathrm{~cm}$; CV 1.3). This winter lacked a preseason, and we did not compare low to high snow periods. Moreover, no snowmobile activity occurred in Juneau Creek during the second winter of 2007-2008, due to a National Forest closure (mean snow accumulation $=34.5 \mathrm{~cm}$; CV 21.1). We considered this entire winter a preseason (Table 1).

\section{Data analyses}

We used the RSF approach described by Sawyer et al. (2006, 2007, 2009) to model moose habitat use and distribution in Placer Valley and Juneau Creek. We developed the RSF models with the moose location data obtained during the periods corresponding to snowmobile use, for the 20062007 winter, in each location. Moose data obtained during the 2007-2008 winter was used for model validation.

Specifically, our approach relied on fitting generalized linear models to relate the probability of use (or relative frequency) by moose within a study area, during a specified period, to habitat characteristics (Sawyer et al. 2009). The approach consisted of four steps. Namely, we (1) measured predictor variables at systematically selected circular sampling units, (2) estimated the relative frequency of use in the sampling units for all collared moose, (3) modeled the relative frequency of use by moose as a function of the predictor variables, and (4) bootstrapped individual animals to account for the fact that individual moose was likely to respond differently to human disturbances.

Study areas were identified by buffering all moose locations by $1 \mathrm{~km}$ and creating a minimum convex polygon around them. This is standard practice for identifying second order habitat selection (Sawyer et al. 2009). Sampling units for measuring the habitat variables were circular units with $200 \mathrm{~m}$ radii. This size captured differences in relative frequency of use and matched the spatial heterogeneity of the landscape (Sawyer et al. 2009). These sampling units were 
selected via a systematic sample with a random start. They represented the entire study area in respect to special extent and habitat characteristics.

For each sampling unit, we counted the number of moose locations within it and measured average elevation (kilometers), average slope (percent), distance to forage (kilometers), distance to cover (kilometers), distance to road (kilometers), distance to railroad (kilometers), distance to snowmobile trail (kilometers), and the percentage of area with snowmobile trails. Distance to forage included the following categories: aspen (Populus tremuloides), birch (Betula papyrifera), black cottonwood (Populus trichocarpa), mixed deciduous, mixed forest, and willow (Salix ssp.). Distance to cover included black, white, lutz, or sitka spruce (Picea ssp.); mixed conifer; and mountain hemlock (Tsuga mertensiana) vegetation. All vegetation classes were taken from http://www. kenaiwatershed.org/research/Watershed_atlas_pdfs/KNWR_ vegetation.pdf. The maximum distances to road, railroad, and snowmobile trail were set to $3 \mathrm{~km}$ based on the presumption that moose do not respond to these anthropogenic features or human disturbance beyond $3 \mathrm{~km}$. Similar analyses for other mammals including elk (Rowland et al. 2000), lynx (Kolbe et al. 2007) caribou (Preisler et al. 2006), and mule deer (e.g., Sawyer et al. 2006, 2009) have seen maximum effects at distances $<3 \mathrm{~km}$.

Before modeling habitat use, we conducted a Pearson's pairwise correlation analysis to identify potential multicolli nearity issues. If two variables were highly correlated (| $r \mid>0.70$ ), both variables were not allowed in the same model.

The relative frequency of locations from the GPS-collared moose found in each sampling unit was an empirical estimate of probability of use by the moose. We used an offset term (McCullagh and Nelder 1989) in the GLM to estimate probability of use by the GPS-collared moose as a function of a linear combination of predictor variables, plus or minus an error term assumed to have a negative binomial distribution. The negative binomial distribution allows for overdispersion (White and Bennetts 1996). In this application, overdispersion is due to many sampling units with zero locations and many sampling units with larger numbers of moose locations. The form of the GLM used was:

$\ln \left(E\left[l_{i}\right]\right)=\ln ($ total $)+\beta_{0}+\beta_{1} X_{1}+\ldots+\beta_{p} X_{p}$,

which is equivalent to

$$
\begin{aligned}
& \ln \left(\mathrm{E}\left[l_{\mathrm{i}} / \text { total }\right]\right)=\ln \left(\mathrm{E}\left[\text { relative frequency } y_{\mathrm{i}}\right]\right) \\
& \quad=\beta_{0}+\beta_{1} \mathrm{X}_{1}+\ldots+\beta_{\mathrm{p}} \mathrm{X}_{\mathrm{p}}
\end{aligned}
$$

where $l_{i}$ is the number of GPS-collared moose locations within sampling unit $i$, total is the total number of GPScollared moose locations within the study area, $\beta_{0}$ is an intercept term, $\beta_{1}, \ldots, \beta_{\mathrm{p}}$ are unknown coefficients to be estimated for habitat variables $X_{1}, \ldots, X_{p}$, and $E[$.] denotes the expected value. The offset term, $\ln$ (total), converts the response variable from an integer count to a relative frequency by dividing the number of collared moose locations in each sampling unit by the total number of moose locations. This approach estimated the probability of use by the collared moose for each sampling unit as a function of predictor variables (Manly et al. 2002). Models were fit using the negative binomial function (glm.nb) in the MASS contributed package (Venables and Ripley 2002) for the R language and environment for statistical computing (R Development Core Team 2012). This function includes maximum likelihood estimation of the dispersion parameter for the negative binomial GLM. Because of gaps between sampling units, predictions from Eq. 1 are not subject to a unit-sum constraint. The final RSF represents probability of use, so is termed a resource selection probability function (RSPF; Manly et al. 2002).

For each geographical area, we pooled all moose location data to estimate one model for all animals within each period. Animals providing more data had more weight in the estimates of coefficients and standard errors for the final model (Thomas and Taylor 2006). To estimate standard errors (SEs) and $90 \%$ confidence intervals (CIs) for model coefficients, we bootstrapped data from the individual animals 500 times (Manly 2007). Bootstrapping individuals treated the animal as the experimental unit and ensured that we were estimating the correct error for population level selection (Thomas and Taylor 2006). Percentile-based CIs were reported, and coefficients with $90 \%$ CIs that did not encompass 0.0 were considered statistically significant $(\alpha=0.10)$.

For Placer Valley, datasets for the preseason were small, which precluded the use of bootstrapping techniques on individuals. Instead, confidence estimates were based on pooled data for all moose. This procedure excluded between animal variation, narrowing the CI estimates.

In Placer Valley, we began by determining which model gained the most support for predicting moose preferences during the snowmobile period (2006-2007), based on AIC criteria (Burnham and Anderson 2002). We determined a priori that the explanatory variables of elevation and slope would occur in all models, as these variables were likely a proxy for snow depth and gradient of terrain. We then approached model selection using two stages. The first stage used AIC criteria to determine if distance to forage and/or distance to cover should enter the final RSPF. Only the best model containing these explanatory variables entered the second stage (Arnold 2010). This second stage used AIC criteria to determine if a substantial portion of the remaining variation in the moose location data could be explained by anthropogenic factors (i.e., distance to road, distance to snowmobile track, distance to railroad, 
and percent of circular unit covered by snowmobile tracks). Selection of the anthropogenic explanatory variables occurred in a stepwise fashion, proceeding until the AIC value for the model could no longer be reduced. Due to high correlations between some variables (e.g., distance to snowmobile track and percent snowmobile track), not all anthropogenic variables were included in the same model.

The model gaining most support for predicting moose preferences during the snowmobile period was used to estimate parameter coefficients for the 2006-2007 preseason, high and low snow periods. This approach enabled evaluating how moose selection for the same variables may change, before snowmobile activity occurred. For example, if moose were averse to snowmobile activity, then preferences for areas dense with trails should show a negative parameter (as the density of snowmobile activity increases, moose use decreases). Displacement would have occurred if this parameter was positive during the preseason. This would indicate that moose were attracted to the area before snowmobile activity, but then avoided those places after it began. The effects of such displacement could be detrimental, where moose also positioned further from areas with adequate forage and cover during the snowmobile period.

We validated the model describing moose behavioral choices during the snowmobile period of 2006-2007 with moose and covariate data from the corresponding snowmobile period in 2007-2008. We also validated the 2006-2007 preseason models with preseason data from the winter of 2007-2008. The predictions were placed into 20 bins of equal area, and the count of use in each bin was compared to the bin rank using Spearman's rank correlation coefficient (Sawyer et al. 2009; Coe et al. 2011).

We took a similar approach in Juneau Creek. We began by determining which model was best supported by data describing when snowmobile activity occurred during the 2006-2007 winter (using AIC criteria; Burnham and Anderson 2002). We used this same model structure on the 2006-2007 postseason. As above, we estimated parameter coefficients and evaluated any coefficient changes between periods. We did not apply the during recreation model on the 2006-2007 preseason since we lacked sufficient data.

We validated the model describing the during recreation period with data from the entire second winter, a period without snowmobiles, using Spearman's rank correlation coefficient. If the model describing moose choices during snowmobile recreation validated well with data describing moose choices without snowmobile recreation, it would indicate little effects of snowmobile activity on moose habitat choices, as one season had snowmobiling and the other did not.

\section{Results}

\section{Literature review}

Seventeen publications document the effects of snowmobiles and other forms of winter recreation on moose and northern ungulates (Table 2). Most studies evaluate disturbances based on behavioral observations and measure the distances between the disturbing agent (i.e., snowmobile) and the animal, at the time of reaction. Sometimes these distances and times are quantified to estimate energetic costs (i.e., Neumann et al. 2010).

Four studies explore disturbances to moose from winter recreational activity, with two focused on snowmobiles. One of them reports that moose within $150 \mathrm{~m}$ of snowmobile trails were more likely to alter their behavior from the activity (e.g., feeding, bedding). The frequency of snowmobiles did not affect moose numbers in the study area (Colescott and Gillingham 1998). In the second publication, Nordic skiing and snowshoeing elicited greater disturbances to moose than snowmobile use (Rudd and Irwin 1985).

The remaining two publications covered Nordic skiers. In one, skier activity reduced moose numbers within $500 \mathrm{~m}$ of ski trails, and moose wintered in areas with lower skiing activity (Ferguson and Keith 1982). During the second study, skiers disturbed moose for $180 \mathrm{~s}$, and when disturbed, moose movements increased by 33 times for the first hour after disturbance. This doubled moose use of energy (Neumann et al. 2010).

Thirteen studies examine responses of other ungulates (caribou, elk, deer, bison, reindeer, and muskox) to winter recreation activity (Table 2). Disturbances to animals occur inconsistently (within and across species), and the interpretations of disturbance vary from body movement to geographical displacement. For example, white-tailed deer within $61 \mathrm{~m}$ of a trail were sometimes disturbed from snowmobiles (e.g., disturbance measured by the animals walking or moving their heads; Eckstein et al. 1979). Dorrance et al. (1975) also report variation in deer disturbance, but when deer are displaced, they relocate within $200 \mathrm{~m}$ of a snowmobile trail. McLaren and Green (1985) measured an initial reaction by muskox individuals to snowmobiles at $345 \mathrm{~m}$. Freddy et al. (1986) found that flight responses in mule deer occurred at $191 \mathrm{~m}$ for people on snowshoes and $133 \mathrm{~m}$ for snowmobiles. Elsewhere, reindeer groups fled from snowmobiles occurring within $80 \mathrm{~m}$ (Tyler 1991). Some elk within $400 \mathrm{~m}$ of a skier in an area infrequently used by people would move $1,675 \mathrm{~m}$. Elk more conditioned to human activity, if displaced, moved $40 \mathrm{~m}$ (Cassirer et al. 1992). Borkowski et al. (2006) report that elk did not flee from snowmobiles or snow coaches. Contrarily, Seip et al. (2007) found snowmobile use displacing caribou from areas of high habitat quality (Table 2). 


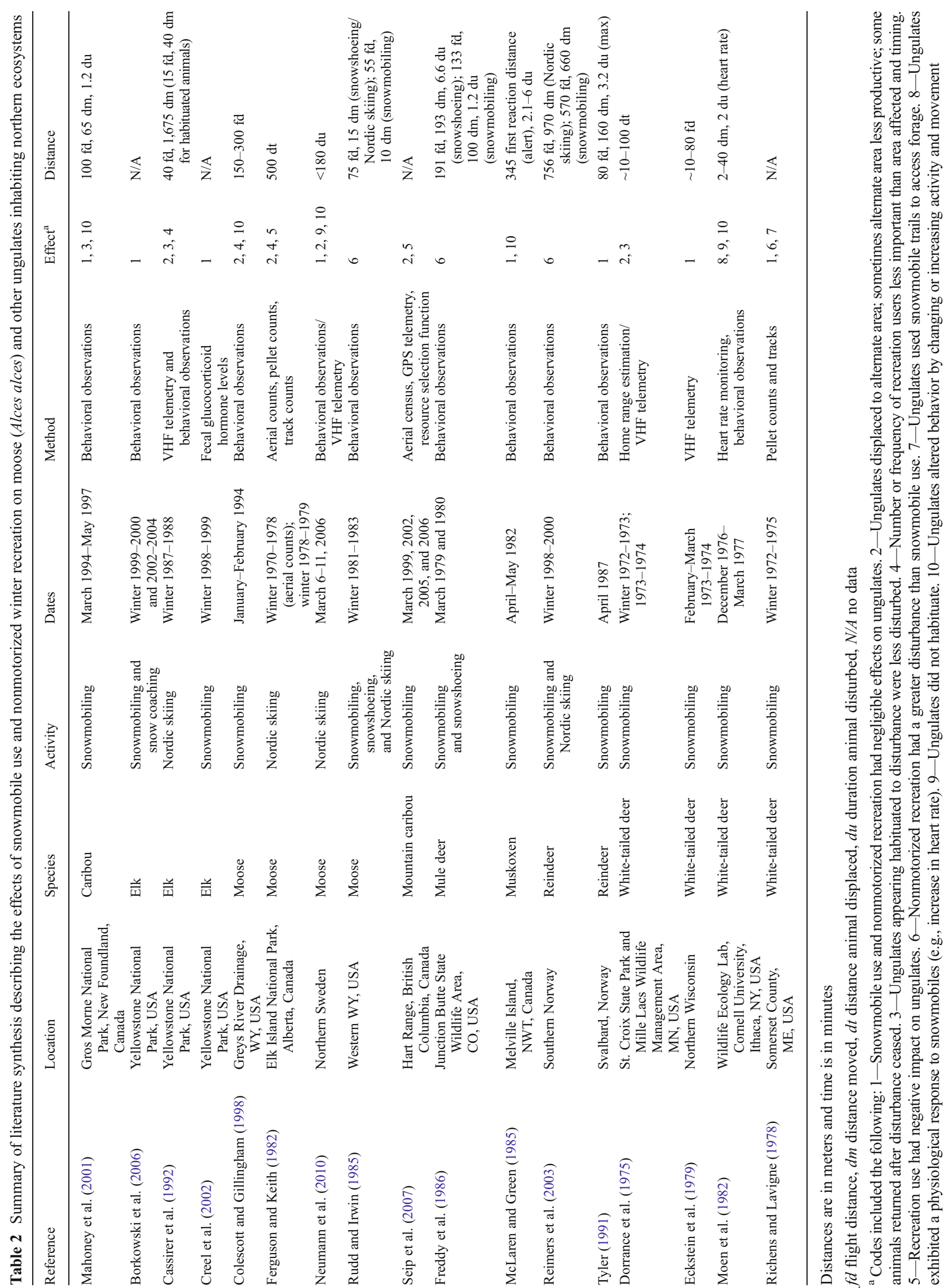


As a measure of physiological stress, Moen et al. (1982) demonstrate that heart rates of white-tailed deer increase from snowmobile activity within $40 \mathrm{~m}$, for an average of $2 \mathrm{~min}$, without signs of habituation. The effects are unknown. For elk, the amount of glucocorticoid in feces paralleled the variation in the number of snowmobiles present (Creel et al. 2002). There was no evidence that snowmobile activity negatively affects elk population dynamics (Creel et al. 2002).

Guidelines describing the effects of winter recreation on northern ungulates

Our literature synthesis exposed how various forms of winter recreation can elicit diverse and inconsistent behavioral responses from ungulates. Sometimes animals are undisturbed by winter recreation, while at other times they are disturbed and leave the area. Animals may or may not return after the disturbance.

Despite this, commonalities emerged. Some ungulate responses appear independent of species or geographical location. Explanations for the different outcomes depend on the duration of the activity, the predictability of disturbance, the type of recreation, and habitat availability. Information on these factors enabled formulating six guidelines that describe the effects of winter recreation on ungulates.

1. Recreation causes the most disturbances to ungulates when it is unpredictable in timing and geographical location.

2. The size of the area having the recreational activity is more influential than the magnitude of users or intensity of use. Recreation spanning larger areas tends to have more negative impacts to ungulates than recreation occurring in smaller areas.

3. The duration of the activity is more influential than the magnitude of users or intensity of use. Short-term disturbance events are less likely to reduce the physical well-being of ungulates. Therefore, months of recreation activity generate negative effects more than recreation activity spanning a few days or weeks.

4. Because motorized disturbances have a greater spatial footprint, there is a higher likelihood for them to disturb ungulates.

5. Nonmotorized recreation generates greater disturbances to wildlife than motorized activities such as snowmobiling. An animal is at risk of displacement when humans afoot are within approximately $15-756 \mathrm{~m}$ and snowmobiles $10-570 \mathrm{~m}(\mathrm{~min} / \mathrm{max})$. Animals tend to move further from nonmotorized activity $(15-1,675$ vs. 10 $660 \mathrm{~m}(\mathrm{~min} / \mathrm{max})$ for motorized) and disturbances last longer $(<3 \mathrm{~h}(\max )$ nonmotorized vs. $<6$ min $(\max )$ motorized).
6. Long-term concerns of disturbance occur when recreation use is high enough to displace animals to poor quality habitats for extended periods.

The authors discussed point 1 most. Point 6 was least tested. Indeed, only two studies conclude negative impacts to ungulates based on displacement (Nordic skiers - Ferguson and Keith 1982; snowmobiles-Seip et al. 2007). The field studies provided more information for these two guidelines.

Field evaluations

During snowmobile activity in Placer Valley, the model receiving most support contained variables of elevation $(\beta=-3.89)$, slope $(\beta=-0.11)$, distance to forage $(\beta=-3.43)$, distance to road $(\beta=0.78)$, and percentage of snowmobile trails $(\beta=-0.05)$ (Tables 3 and 4). There were no competing models (Burnham and Anderson 2002; Arnold 2010). Positive parameters described selection increasing as the variables increased. For example, moose preferences increased with distances from roads. Negative parameters indicated moose preferences increasing as the variable declined. Hence, moose preferred lower elevations, gentle slopes, and areas close to forage. Moose avoided areas of high snowmobile trail density (Table 4).

We applied this model describing moose preferences during the snowmobile period to data describing the prior two preseason periods. Moose always preferred areas near forage, low slope, and distant from roads (Fig. 2). During the low snow, preseason period, values for parameter estimates were as follows: elevation $-\beta=3.37$, slope $-\beta=-0.24$, distance to forage $-\beta=-7.60$, percent snowmobile trails $-\beta=0.05$, and distance to roads $-\beta=1.93$ (Table 4 , Fig. 2). Changes in parameter estimates suggested the effects of snowmobile activity on moose behavior. During low snow conditions, moose preferred areas with high elevation. Moose also selected locations soon to have high proportions of snowmobile trails, with a positive, exponentially shaped relationship. The probability of use for areas that would receive $>60 \%$ snowmobile trails was $20-100 \%$ (Fig. 3).

During high snow conditions, parameter estimates changed by the following: elevation $(\beta=-9.29)$, slope $(\beta=-0.07)$, distance to forage $(\beta=-1.92)$, distance to $\operatorname{road}(\beta=0.66)$, and percentage of snowmobile trails $(\beta=-0.01)$ (Table 4). Moose preferred gentle slopes and lower elevations, proximity to forage, and greater distances from roads. The probability of a moose being in an area increased as the percentage of snowmobile trails declined. The relationship was linear (Fig. 3). Moose avoidance or selection for areas with high density of future trails remained indeterminate, since confidence intervals overlapped zero (Table 4).

We identified the following pattern: In early winter, moose selected areas that would eventually receive high snowmobile 
Table 3 Comparison of models describing moose (Alces alces) habitat preferences for eight variables in three different periods during the winter of 2006-2007 with snowmobile recreation at Placer Valley in south-central Alaska, USA

\begin{tabular}{|c|c|c|c|c|c|}
\hline $\begin{array}{l}\text { Stage of model } \\
\text { selection }\end{array}$ & Covariates & $k$ & AIC & $\triangle \mathrm{AIC}$ & $\begin{array}{l}\text { Model } \\
\text { weight }\end{array}$ \\
\hline \multirow[t]{3}{*}{1} & Elevation + slope + distance to cover & 5 & $6,409.6$ & 46.8 & 0.0 \\
\hline & Elevation + slope + distance to forage + distance to cover & 6 & $6,363.6$ & 0.8 & 0.4 \\
\hline & Elevation + slope + distance to forage & 5 & $6,362.8$ & 0.0 & 0.6 \\
\hline \multirow[t]{7}{*}{2} & Elevation + slope + distance to forage + distance to railroad & 6 & $6,361.9$ & 61.5 & 0.0 \\
\hline & Elevation + slope + distance to forage + distance to snowmobile trail & 6 & $6,360.2$ & 59.8 & 0.0 \\
\hline & Elevation + slope + distance to forage $+\%$ snowmobile trail & 6 & $6,353.7$ & 53.3 & 0.0 \\
\hline & Elevation + slope + distance to forage + distance to road & 6 & $6,328.0$ & 27.6 & 0.0 \\
\hline & Elevation + slope + distance to forage + distance to road + distance to snowmobile trail & 7 & NA & NA & NA \\
\hline & Elevation + slope + distance to forage + distance to road + distance to railroad & 7 & NA & NA & NA \\
\hline & Elevation + slope + distance to forage + distance to road $+\%$ snowmobile trail & 7 & $6,300.4$ & 0.0 & 1.0 \\
\hline
\end{tabular}

The letters "NA" indicate a model that did not converge. Model weights were based on AIC values within each stage of model selection

use. Moose probability of use was $\geq 20 \%$ for areas that would later receive $60-100 \%$ snowmobile trails. As snow depth increased, preferences for areas with future snowmobile trails tapered. Now, moose were $30-50 \%$ more likely to remain in areas that would later have a density of 50-100\% snowmobile trails. When snowmobile activity occurred, moose retreated to places with low percentages of snowmobile trails. Moose probability of being in an area with $\geq 50 \%$ snowmobile trails fell $<10 \%$. This occurred despite declining depth of snow at the valley. If snow depth was the primary factor, then moose use of areas with a high density of trails should have increased, since the period with snowmobiling had less snow than the period prior without snowmobiling. Instead, the presence of snowmobile recreation was the primary factor. Moose were displaced to areas with proximity to forage similar to their original locations (Table 4). The geographical locations used before snowmobile recreation and after were equivalent in area $(\sim 50 \mathrm{~km} 2)$, so moose density in these habitats remained unchanged. Moreover, these locations had similar model parameters (regarding distances to forage, roads, and slope).

The model describing moose preferences during snowmobile activity was validated with moose and covariate data during the 2007-2008 snowmobile season (Spearman's rank coefficient, $r 2=0.81$ ). The entire preseason model of 2006 2007 (low and high snow periods combined) was validated against data gained during the $2007-2008$ preseason $(r 2=0.84)$. Lastly, the preseason low snow period was validated against the entire 2007-2008 preseason $(r 2=0.93)$. High values of validation support the models' predictive abilities.

For Juneau Creek, we identified the model with most support, based on AIC criteria, during the period of snowmobile recreation (Table 5). Moose showed no preference for elevation, slope, or proximity to roads, as all confidence intervals spanned 0 (Table 6). Moose preferences increased for areas with closer distances to forage and cover. As distances to the Resurrection Trail increased, moose preferences declined, indicating attraction to the trail or features associated with it.
Table 4 Parameters, parameter estimates, and $90 \%$ confidence intervals (LL, UL) for variables included in the most supported model describing moose (Alces alces) preferences during the snowmobile period in Placer Valley, Alaska, USA (winter of 2006-2007; Table 3), applied to the two preseason periods

\begin{tabular}{|c|c|c|c|c|c|c|c|c|c|}
\hline \multirow[t]{3}{*}{ Parameter } & \multicolumn{3}{|c|}{ Preseason 2006-2007 } & \multicolumn{3}{|c|}{ Preseason 2006-2007 } & \multicolumn{3}{|c|}{ During season 2006-2007 } \\
\hline & \multicolumn{3}{|c|}{ Low snow } & \multicolumn{3}{|c|}{ High snow } & \multirow[b]{2}{*}{ Estimate } & \multirow[b]{2}{*}{ LL } & \multirow[b]{2}{*}{ UL } \\
\hline & Estimate & LL & $\mathrm{UL}$ & Estimate & LL & $\mathrm{UL}$ & & & \\
\hline Intercept & -11.64 & -12.28 & -10.99 & -6.69 & 7.34 & -6.03 & -7.11 & -7.45 & -6.78 \\
\hline Elevation & 3.37 & 1.98 & 4.77 & -9.29 & -11.57 & -7.01 & -3.89 & -4.76 & -3.01 \\
\hline Slope (\%) & -0.24 & -0.27 & -0.21 & -0.07 & -0.11 & -0.04 & -0.11 & -0.13 & -0.09 \\
\hline Distance to forage & -7.60 & -9.56 & -5.63 & -1.92 & -3.64 & -0.19 & -3.43 & -4.30 & -2.56 \\
\hline Distance to road & 1.93 & 1.68 & 2.19 & 0.66 & 0.41 & 0.92 & 0.78 & 0.65 & 0.92 \\
\hline$\%$ Snowmobile trail & 0.05 & 0.03 & 0.06 & -0.01 & -0.03 & 0.75 & -0.05 & -0.06 & -0.04 \\
\hline
\end{tabular}


Fig. 2 Plots describing the probability of use for four variables, across three periods, by moose inhabiting Placer Valley, south-central Alaska. The three periods include (1) preseason with low snow conditions (solid line), (2) preseason with high snow conditions (dashed line), and (3) during snowmobile recreation (dotted line). Panels represent the following four variables: a elevation, $\mathbf{b}$ percent slope, $\mathbf{c}$ distance to forage (kilometers), and $\mathbf{d}$ distance to road (kilometers). Moose preferences for these four parameters were not influenced by snowmobile use in Placer Valley
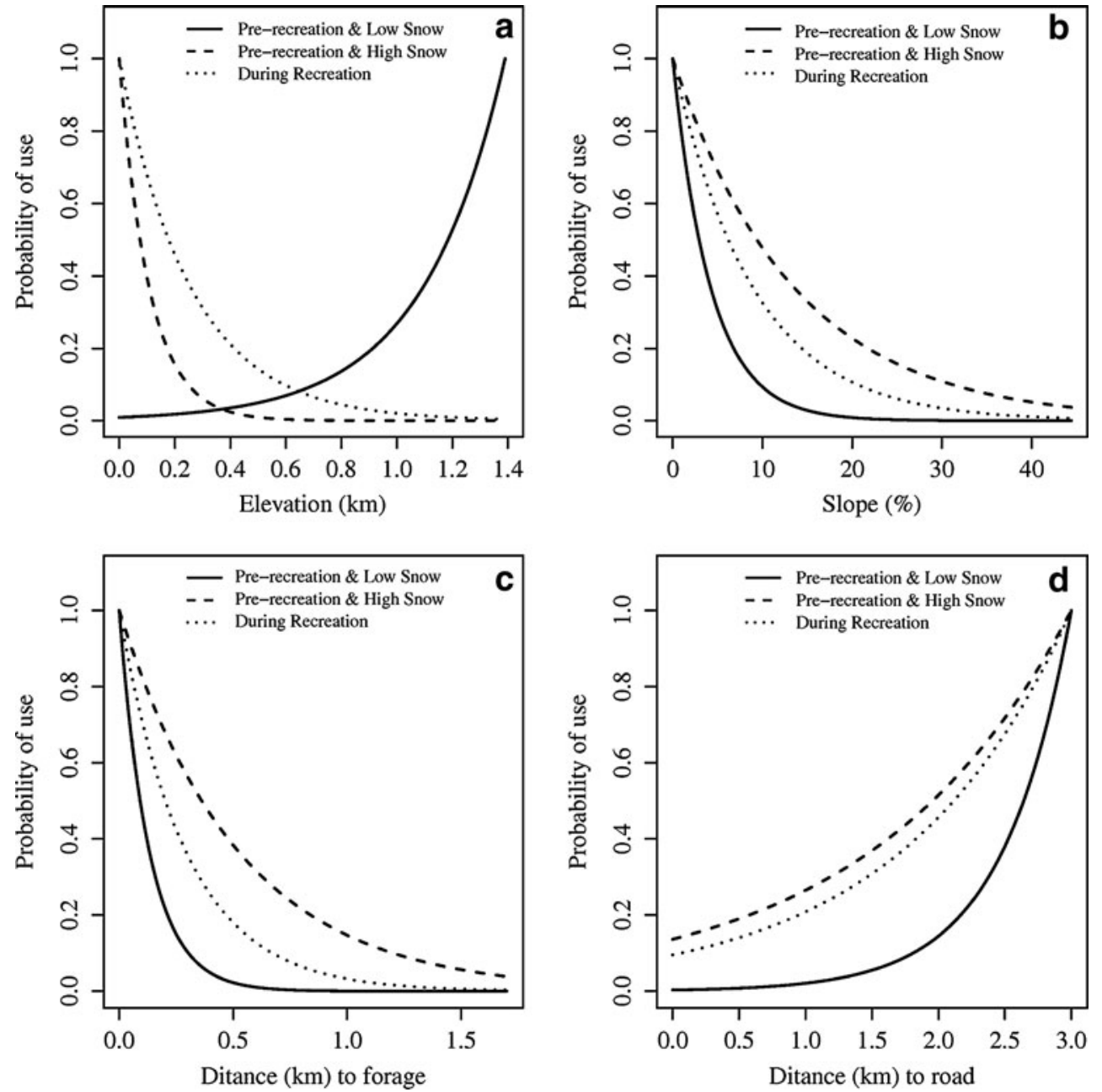

We calculated parameter estimates for the 2006-2007 postseason using the same model developed during the recreation period. Model analysis suggests that moose preferred lower elevations and steeper slopes (Table 6). Moose continued to prefer locations near forage and cover. Model results are similar, particularly with respect to the variable describing distances to the Resurrection Trail.

The model describing moose preferences during snowmobile activity was validated with data spanning December 1, 2007-March 31, 2008 ( $r 2=0.86)$. During these dates, Juneau Creek was closed to snowmobiles. The post-recreation model also validated well against the 2007-2008 winter $(r 2=0.83)$. The validation demonstrates similarity in moose behaviors during periods with and without snowmobiling.

Results of the field studies corroborated that recreation, when unpredictable in time and space, caused more disturbances to ungulates than predictable recreation. We also demonstrated that unpredictable recreation spanning long durations (months) can displace ungulates to different locations. In our study, animals moved to locations with similar habitat characteristics. This reduced the potential for longterm negative effects.

\section{Discussion}

We reviewed literature describing the responses of northern ungulates to various forms of winter recreation and quantified moose behavioral changes to snowmobile activity in southcentral Alaska. Our goal was to formulate and evaluate guidelines describing conditions when winter recreation may be detrimental to ungulates, to help resource managers balance recreation with wildlife stewardship. We offered six guidelines. Recreation impacts on ungulates increase when it occurs over long periods and across large areas, with disturbances unpredictable in location and time (guidelines 1-3). Because motorized use covers greater area, the numbers of disturbance events increase (guideline 4). However, these disturbances have less affect than disturbances generated by nonmotorized users (guideline 5). Lastly, the presence of alternative habitats for animals to relocate reduces the impacts of disturbances from winter recreation (guideline 6). Managers can use these guidelines for predicting the responses of ungulates to recreation in any given area.

The second and third guidelines are straightforward. Recreation occurring in small areas has less impact relative to 


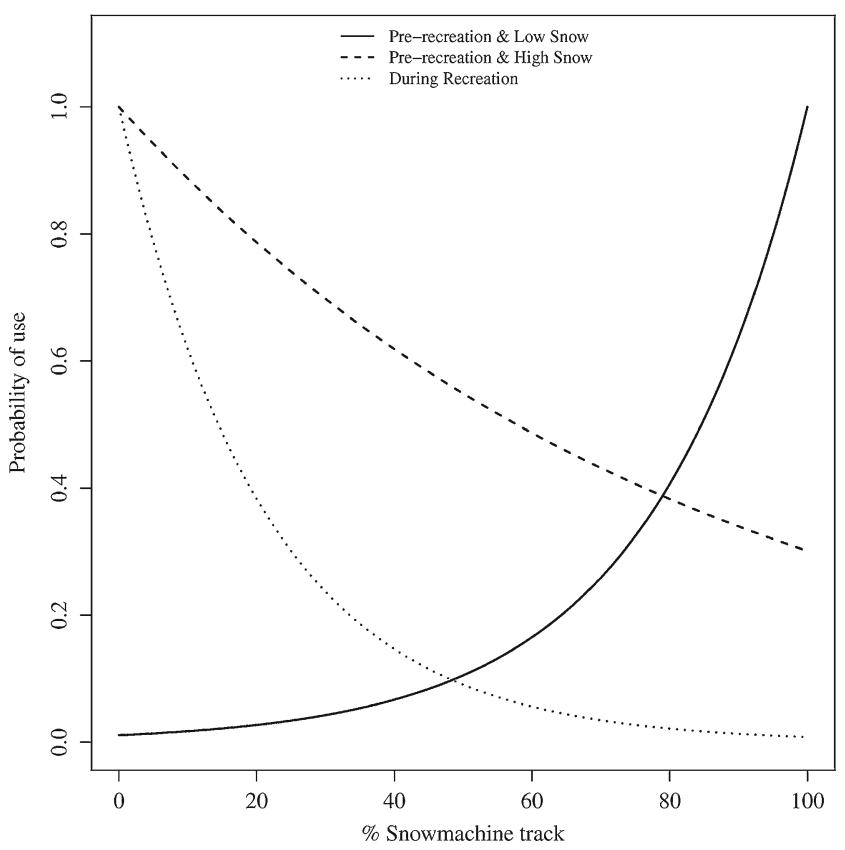

Fig. 3 Plot describing moose probability of use for areas that vary in their proportion of snowmobile trails, across three periods, by moose inhabiting Placer Valley, south-central Alaska. The three periods include (1) preseason with low snow conditions (solid line), (2) preseason with high snow conditions (dashed line), and (3) during snowmobile recreation (dotted line). Probability of use is determined by using the best model describing moose preferences during snowmobile recreation, applied to the other periods. During the preseason and low snow period, moose selected areas that would have high density of snowmobile use, with a positive, exponentially shaped relationship. Moose probability of use was $\geq 20 \%$ for locations that would be covered $>60 \%$ with snowmobile trails. During preseason and high snow depth, moose preferences declined linearly with the proportion of snowmobile trails. During snowmobile recreation, the probability of moose using areas with increasing proportion of snowmobile trails declined in exponential form. The probabilities of moose being in locations with percent snowmobile trails $\leq 30 \%$ and below were $20-100 \%$

recreation occurring across large areas. Moreover, recreation activities occurring over short periods (days or hours) have less impact than those occurring over longer periods (months). We addressed the remaining guidelines in turn.
Predictability

When recreation activity is visually or acoustically predictable in location and time, then animals can habituate (Dorrance et al. 1975; Schultz and Bailey 1978; Epsmark and Langvatn 1985; Westworth et al. 1989; Cassirer et al. 1992). Recreation that is unpredictable in location or time can cause displacement (Kuck et al. 1985; Freddy et al. 1986; Cassirer et al. 1992). Most studies report that when displacement occurred, it was temporary, with animals returning after disturbance (Dorrance et al. 1975; Richens and Lavigne 1978; Tyler 1991; Cassirer et al. 1992; Andersen et al. 1996). Deer, for example, did not abandon bedding and feeding sites from snowmobile disturbances, and some followed snowmobile trails for short distances when near major bedding areas (Richens and Lavigne 1978). Eckstein et al. (1979) report no differences between the sizes of home ranges or habitat use for white-tailed deer between areas with and without snowmobiles. Fewer studies demonstrate winter recreation causing permanent displacement in ungulates (Dorrance et al. 1975; Ferguson and Keith 1982).

\section{Amount and type of recreation}

Because motorized activity is more likely to cover larger areas than nonmotorized recreation, the number of ungulate disturbance events seems greater. Despite this, when disturbance events occur, nonmotorized recreation causes greater disturbances to ungulates than motorized users (e.g., Richens and Lavigne 1978; Eckstein et al. 1979; Rudd and Irwin 1985; Freddy et al. 1986; Canfield et al. 1999; Reimers et al. 2003). Therefore, nonmotorized recreation causes fewer, stronger disturbance effects in relatively smaller areas, while motorized recreation generates more, weaker disturbances across larger areas. Nonmotorized activity also causes animals to flee sooner and move further. The disturbances last longer. For instance, it takes longer for heart rates of moose to normalize after responding to nonmotorized

Table 5 Comparison of models describing moose (Alces alces) habitat preferences for seven variables during the winter of 2006-2007 with snowmobile recreation at Juneau Creek in south-central Alaska, USA. Model weights were based on AIC values within each stage of model selection

\begin{tabular}{|c|c|c|c|c|c|}
\hline $\begin{array}{l}\text { Stage of model } \\
\text { selection }\end{array}$ & Covariates & $k$ & $\mathrm{AIC}$ & $\triangle \mathrm{AIC}$ & $\begin{array}{l}\text { Model } \\
\text { weight }\end{array}$ \\
\hline \multirow[t]{3}{*}{1} & Elevation + slope + distance to cover & 5 & $17,491.3$ & 53.5 & 0.0 \\
\hline & Elevation + slope + distance to forage & 5 & $17,479.1$ & 41.3 & 0.0 \\
\hline & Elevation + slope + distance to forage + distance to cover & 6 & $17,437.8$ & 0.0 & 1.0 \\
\hline \multirow[t]{4}{*}{2} & Elevation + slope + distance to forage + distance to cover + distance to road & 7 & $17,436.4$ & 169.2 & 0.0 \\
\hline & Elevation + slope + distance to forage + distance to cover $+\%$ snowmobile trail & 7 & $17,413.9$ & 146.7 & 0.0 \\
\hline & Elevation + slope + distance to forage + distance to cover + distance to snowmobile trail & 7 & $17,295.1$ & 27.9 & 0.0 \\
\hline & $\begin{array}{l}\text { Elevation }+ \text { slope }+ \text { distance to forage }+ \text { distance to cover }+ \text { distance to snowmobile trail }+ \\
\text { distance to road }\end{array}$ & 8 & $17,267.2$ & 0.0 & 1.0 \\
\hline
\end{tabular}


Table 6 Parameters, parameter estimates, and $90 \%$ confidence intervals (LL, UL) for variables included in the best model describing moose (Alces alces) preferences during the snowmobile period in Juneau Creek, Alaska, USA (winter of 2006-2007), applied to the post-recreation period

\begin{tabular}{|c|c|c|c|c|c|c|}
\hline \multirow[t]{2}{*}{ Parameter } & \multicolumn{3}{|c|}{ During season 2006-2007 } & \multicolumn{3}{|c|}{ Post-recreation 2006-2007 } \\
\hline & Estimate & LL & UL & Estimate & LL & UL \\
\hline Intercept & -7.204 & -8.448 & -6.222 & -5.163 & -6.993 & -5.071 \\
\hline Elevation & 0.466 & -3.467 & 2.847 & -5.278 & -7.482 & -0.795 \\
\hline Slope (\%) & -0.007 & -0.025 & 0.017 & 0.066 & 0.017 & 0.080 \\
\hline Distance to forage & -2.634 & -5.651 & -1.235 & -0.959 & -2.468 & -0.213 \\
\hline Distance to cover & -1.395 & -2.071 & -0.498 & -1.786 & -2.539 & -0.039 \\
\hline Distance to snowmobile trail & -0.720 & -1.270 & -0.476 & -0.884 & -1.272 & -0.510 \\
\hline Distance to road & 0.410 & -0.180 & 1.224 & 0.217 & -0.106 & 0.856 \\
\hline
\end{tabular}

disturbances (Andersen et al. 1996), even though animals are aware of snowmobiles sooner (Reimers et al. 2003).

Irrespective of the type of winter recreation, animals respond to the initial event, even at low levels. What matters is the amount of time the recreation occurred and the area covered (Cassirer et al. 1992). Hence, the amount of use-be it nonmotorized or motorized - has little influence (Geist 1971; Dorrance et al. 1975; Ferguson and Keith 1982; Cassirer et al. 1992; Colescott and Gillingham 1998). This made quantifying the intensity of recreation in our study sites unwarranted.

\section{Habitat availability}

Understanding ungulate behavioral responses to recreation relies on evaluating recreation in the context of habitat quality and quantity, within the geographical area. Seemingly, an animal in quality habitat with winter recreation would be displaced more readily if vacant, equally good winter habitat occurred nearby, without the activity. Alternatively, animals inhabiting quality habitat are probably less likely to permanently relocate to poorer habitat, when the quality habitat is in short supply. Then, animals may temporarily vacate an area during recreation and return when recreation ceases.

For example, imagine a $100-\mathrm{km} 2$ area with 100 moose (1 moose $/ \mathrm{km} 2$ ). In winter, because of snowmobile activity, moose used only half of this area $(50 \mathrm{~km} 2$ at 2 moose $/ \mathrm{km} 2)$. Would this situation be detrimental to the population? The answer depends on the relationships between the quality and quantity of habitat in an area, moose density, and the amount of time spent in it. Displacement would be most problematic if ungulates relocate to environments with low quality food, or if they aggregate into smaller areas of preferred habitat, for extended periods, such that these habitats are unable to sustain them. The worst situation occurs when animals avoid quality winter habitat during the severest parts of winter (extreme cold and deep snow). Then, displacement increases energy expenditure, weakening individual survival (Hobbs 1989). For example, disturbances that cause large ungulates to stand from a lying position can consume $25 \%$ more energy than remaining idle (Parker et al. 1984; Renecker and Hudson 1986). Such displacement was quantified by two studies (Colescott and Gillingham 1998; Seip et al. 2007). Others hypothesized the outcome (e.g., Eckstein et al. 1979; Tyler 1991).

\section{Field evaluation}

Our field evaluation examined recreations' predictability on ungulate behavior and identified conditions when ungulates may be displaced to poor quality habitats for extended periods. This investigation also served to evaluate the other guidelines. For example, in Placer Valley, recreation was unpredictable in location and time, so moose were unlikely to habituate. The size of the recreation area was large, and snowmobile activity lasted 3 months. This increased the number of disturbance events and likelihood of displacement (temporary or permanent). Since recreation was motorized, it also raised the likelihood of disturbance events, but decreased their severity in comparison to nonmotorized users. These circumstances describe a situation where displacement of moose was likely, and snowmobiling would probably be detrimental to moose. However, in Placer Valley, alternative habitats without recreation exist, and these were available for moose to access. During periods of snowmobile activity, moose were displaced, as predicted, but they remained close to forage (Table 4; $11 \%$ of Placer Valley classified as forage). These outcomes infer that snowmobile activity was unlikely to have negative effects on moose residing in Placer Valley. Granted, we do not know what made the locations where snowmobiles occurred attractive to moose during the preseason. The potential exists for the habitats that moose used between periods to differ in quality, despite our classifying them identically.

At Juneau Creek, winter recreation occurred over long periods (2 months), increasing the number of disturbance events and likelihood of displacement. However, human use was confined to a relatively small, linear area (one trail), making recreation more predictable in location and time. 
This should encourage habituation by moose. The valley is also expansive with alternative habitats existing off the main trail (15\% of the area classified as forage). Overall, moose were not displaced in Juneau Creek, but may have habituated to human use. Motorized and nonmotorized recreation shared the trail (snowmobiles, Nordic skiers, ATVs, and snowshoers). Evaluating moose responses to the differing forms of recreation was beyond our scope, although we noted that moose preferences did not change between winters with and without snowmobile use. Moose always preferred areas close to this trail. We concluded that snowmobile activity did not negatively affect moose at Juneau Creek.

Professionals managing areas with ungulates and winter recreation can use these six guidelines, as exemplified above, to predict recreations' effects on ungulates. While subtleties in species-specific responses or locations are likely to exist, these guidelines are designed to apply to any northern ungulate in any of their habitats.

In practice, when applying these guidelines, logistical or fiscal constraints may challenge abilities to gain information describing recreation type, duration, and spatial use. For these situations, the most important requirement would be knowing the location and extent of quality habitat without recreation. This would cover a worst-case scenario of animals relocating to these habitats, where winter recreation long in duration, covering large areas, being nonmotorized and unpredictable. The amount of habitat necessary to minimize the potential for negative effects would depend on the habitat, animal species, and the density of animals anticipated to use it. Provided that a suitable amount of alternative habitats exists, then the influence of snowmobiles and other forms of winter recreation on ungulates is rather benign (e.g., Richens and Lavigne 1978; McLaren and Green 1985; Tyler 1991; Mahoney et al. 2001; Creel et al. 2002; Reimers et al. 2003; Borkowski et al. 2006). If sufficient habitat free of recreation did not exist, and animals were displaced to poor quality habitats, then their nutrient intake would decline, and increases in physiological stress and energy expenditure would ensue. This would reduce individual health and survivorship during winter, contributing toward population declines.

This study built and tested criteria describing when the effects of winter recreation may be detrimental to ungulates. We provided six guidelines. Wildlife managers can use these guidelines for predicting the responses of northern ungulates to recreation in any given area. Such analyses would identify the effects of winter recreation on ungulates.

Acknowledgments We thank the following individuals for project support and advice: Martin Bray, Jose DeCreft, Michelle Dragoo, Howard Golden, Greg Hayward, Dana Kuiper, Michael Litzen, Kristine Metzger, Mike Novy, Susan Oehlers, Terry Onslow, Jeff Selinger, Paula Smith, and Aaron Poe.
Open Access This article is distributed under the terms of the Creative Commons Attribution License which permits any use, distribution, and reproduction in any medium, provided the original author(s) and the source are credited.

\section{References}

Andersen R, Linnell JDC, Langvatn R (1996) Short term behavioral and physiological response of moose (Alces alces) to military disturbance in Norway. Biol Conserv 77:169-176

Arnold TW (2010) Uninformative parameters and model selection using Akaike's information criterion. J Wildl Manag 74:1175-1178

Borkowski JJ, White PJ, Garrott RA, Davis T, Hardy AR, Reinhart DJ (2006) Behavioral response of bison and elk in Yellowstone to snowmobiles and snow coaches. Ecol Appl 16:1911-1925

Bunnell KD, Flinders JT, Wolfe ML (2006) Potential impacts of coyotes and snowmobiles on Lynx conservation in the Intermountain West. Wildl Soc Bull 34:828-838

Burnham KP, Anderson DR (2002) Model selection and multimodel inference: a practical information theoretic approach. Springer, New York

Canfield JE, Lyon LJ, Hillis JM, Thompson MJ (1999) Ungulates. In: Joslin G, Youmans H (eds) Effects of recreation on Rocky Mountain wildlife: a review for Montana Committee of Effects of Recreation and Wildlife. Montana Chapter of the Wildlife Society, Montana, pp 61-625

Cassirer EF, Freddy DJ, Ables ED (1992) Elk response to disturbance by cross-country skiers in Yellowstone National Park. Wildl Soc Bull 20:375-381

Coe PK, Johnson BK, Wisdom MJ, Cook JG, Vavra M, Nielson RM (2011) Validation of elk resource selection models with spatiallyindependent data. J Wildl Manag 75:159-170

Colescott JH, Gillingham MP (1998) Reaction of moose (Alces alces) to snowmobile traffic in the Greys River Valley, Wyoming. Alces 34:329-338

Creel S, Fox EJ, Hardy A, Sands J, Garrott B, Peterson RO (2002) Snowmobile activity and glucocorticoid stress responses in wolves and elk. Conserv Biol 3:809-814

Dorrance MJ, Savage PJ, Huff DE (1975) Effects of snowmobiles on white-tailed deer. J Wildl Manag 39:563-569

Eckstein RG, O’Brien TF, Rongstad OJ, Bollinger JG (1979) Snowmobile effects on movements of white-tailed deer: a case-study. Environ Conserv 6:45-51

Epsmark Y, Langvatn R (1985) Development and habituation of cardiac and behavioral response in young red deer calves (Cervus elephus) exposed to alarm stimuli. J Mammal 66:702-711

Ferguson MAD, Keith LB (1982) Influence of Nordic skiing on distribution of moose and elk in Elk Island National Park, Alberta. Can Field Nat 96:69-78

Freddy DJ, Bronaugh WM, Fowler MC (1986) Responses of mule deer to disturbance by persons afoot and snowmobiles. Wildl Soc Bull 14:63-68

Gasaway WC, Coady JW (1974) Review of energy requirements and rumen fermentation in moose and other ruminants. Nat Can $101: 227-262$

Geist V (1971) A behavioral approach to the management of wild ungulates. In: Duffey E, Watt AS (eds) The scientific management of animal and plant communities for conservation. 11th symposium of the British Ecological Society, Norwich, pp 5413-424

Hobbs NT (1989) Linking energy balance to survival in mule deer: development and test of a simulation model. Wildl Monogr 101:1-31 
James ARC, Stuart-Smith AK (2000) Distribution of caribou and wolves in relation to linear corridors. J Wildl Manag 64:154159

Kolbe JA, Squires JR, Pletscher DH, Ruggiero LF (2007) The effect of snowmobile trails on coyote movements within lynx home ranges. J Wildl Manag 71:1409-1418

Kuck L, Hompland GL, Merrill EH (1985) Elk calf response to simulated mine disturbance in southeast Idaho. J Wildl Manag 49:751-757

Mahoney SP, Mawhinney K, McCarthy C, Anions D, Taylor S (2001) Caribou reactions to provocation by snowmobiles in Newfoundland. Rangifer 21:35-43

Manly BFJ (2007) Randomization, bootstrap, and Monte Carlo methods in biology, 3rd edn. Chapman and Hall, Boca Raton

Manly BFJ, McDonald LL, Thomas DL, McDonald TL, Erickson WP (2002) Resource selection by animals: statistical design and analysis for field studies, 2nd edn. Kluwer Academic, Boston

McCullagh P, Nelder JA (1989) Generalized linear models, 2nd edn. Chapman and Hall, Boca Raton

McLaren MA, Green JE (1985) The reactions of muskoxen to snowmobile harassment. Arctic 38:188-193

Moen AN, Whittemore S, Buxton B (1982) Effects of disturbance by snowmobiles on heart rate of captive white-tailed deer. NY Fish Game J 29:176-183

Nellemann C, JordhØy P, StØen OG, Strand O (2000) Cumulative impacts of tourist resorts on wild reindeer (Rangifer tarandus tarandus) during winter. Arctic 53:9-17

Neumann W, Ericsson G, Dettki H (2010) Does off-trail backcountry skiing disturb moose (Alces alces)? Eur J Wildl Res 56:513-518

Parker KL, Robbins CT, Hanley TA (1984) Energy expenditures for locomotion by mule deer and elk. J Wildl Manag 48:474-488

Preisler HK, Ager AA, Wisdom MJ (2006) Statistical methods for analyzing responses of wildlife to human disturbance. J Appl Ecol 43:164-172

R Development Core Team (2012) R: a Language and environment for statistical computing. Version 2.15.0, Vienna, Austria. http://cran. r-project.org/manuals.html

Reimers E, Eftestøl S, Colman JE (2003) Behavior response of wild reindeer to direct provocation by a snowmobile or skier. J Wildl Manag 67:747-754

Renecker LA, Hudson RL (1986) Seasonal energy expenditures and thermoregulatory response of moose. Can J Zool 64:322327
Richens VB, Lavigne GR (1978) Response of white-tailed deer to snowmobiles and snowmobile trails in Maine. Can Field Nat 92:334-344

Rinaldi TA (2010) Influence of linear features and snowmachine activity on resource selection by wolves. MSc Thesis, University of Northern British Columbia, Prince George, BC pp 132

Rowland MM, Wisdom MJ, Johnson BK, Kie JG (2000) Elk distribution and modeling in relation to roads. J Wildl Manag 64:672-684

Rudd LT, Irwin LL (1985) Wintering moose vs oil/gas activity in western Wyoming. Alces 21:279-298

Sawyer H, Nielson RM, Lindzey F, McDonald LL (2006) Winter habitat selection of mule deer before and during development of a natural gas field. J Wildl Manag 70:396-403

Sawyer H, Nielson RM, Lindzey FG, Keith L, Powell JH, Abraham AA (2007) Habitat selection of Rocky Mountain elk in a non-forest environment. J Wildl Manag 71:868-874

Sawyer H, Kauffman MJ, Nielson RM (2009) Influence of well pad activity on the winter habitat selection patterns of mule deer. $\mathrm{J}$ Wildl Manag 73:1052-1061

Schultz RD, Bailey AJ (1978) Response of national park elk to human activity. J Wildl Manag 42:91-100

Seip DR, Johnson CJ, Watts GS (2007) Displacement of mountain caribou from winter habitat by snowmobiles. J Wildl Manag 71:1539-1544

Thomas DL, Taylor EJ (2006) Study designs and tests for comparing resource use and availability II. J Wildl Manag 70:324-336

Thorne ET, Dean RE, Hepworth WG (1976) Nutrition during gestation in relation to successful reproduction in elk. J Wildl Manag 40:330-335

Tyler JJC (1991) Short-term behavioral response of Svalbard reindeer (Rangifer tarandus platyrhynchus) to direct provocation by a snowmobile. Biol Conserv 56:179-194

Van Ballenberghe V, Ballard WB (1994) Limitation and regulation of moose populations: the role of predation. Can J Zool 72:2071-2077

Venables WN, Ripley BD (2002) Modern applied statistics with S, 4th edn. Springer, New York

Westworth D, Brusnyk L, Roberts J, Veldhuzien H (1989) Winter habitat use by moose in the vicinity of an open pit copper mine in north-central British Columbia. Alces 25:156-166

White RG (1983) Foraging patterns and their multiplier effects on productivity of northern ungulates. Oikos 40:377-384

White GC, Bennetts RE (1996) Analysis of frequency count data using the negative binomial distribution. Ecology 77:2549-2557 